\title{
Structure-dielectric property relationship in polypropylene/multi-element oxide nanocomposites
}

Article

Accepted Version

Azmi, A., Lau, K. Y., Ahmad, N. A., Abdul-Malek, Z., Tan, C. W., Ching, K. Y. and Vaughan, A. S. (2021) Structure-dielectric property relationship in polypropylene/multi-element oxide nanocomposites. IEEE Transactions on Nanotechnology, 20. pp. 377-385. ISSN 1941-0085 doi:

https://doi.org/10.1109/TNANO.2021.3076663 Available at https://centaur.reading.ac.uk/102025/

It is advisable to refer to the publisher's version if you intend to cite from the work. See Guidance on citing.

To link to this article DOI: http://dx.doi.org/10.1109/TNANO.2021.3076663

Publisher: IEEE

All outputs in CentAUR are protected by Intellectual Property Rights law, including copyright law. Copyright and IPR is retained by the creators or other copyright holders. Terms and conditions for use of this material are defined in the End User Agreement. 


\section{CentAUR}

Central Archive at the University of Reading

Reading's research outputs online 


\title{
Structure-Dielectric Property Relationship in Polypropylene/Multi-element Oxide Nanocomposites
}

\author{
Aizat Azmi, Kwan Yiew Lau, Noor Azlinda Ahmad, Zulkurnain Abdul-Malek, Chee Wei Tan, Kuan Yong Ching, \\ and Alun S. Vaughan
}

\begin{abstract}
This paper reports on an investigation into the effects of different multi-element oxide nanofillers on the structure and dielectric properties of polypropylene (PP)-based nanocomposites. Magnesium aluminate $\left(\mathrm{MgAl}_{2} \mathrm{O}_{4}\right)$, calcium carbonate $\left(\mathrm{CaCO}_{3}\right)$ and surface-modified calcium carbonate $\left(\mathrm{CaCO}_{3} \mathrm{~T}\right)$ have been added to the PP to determine their effects on thermal properties, structural changes, dielectric response and breakdown strength. The results show that PP nanocomposites containing $\mathrm{MgAl}_{2} \mathrm{O}_{4}$ possess lowered breakdown strength compared to unfilled PP. In contrast, adding $\mathrm{CaCO}_{3}$ to $\mathrm{PP}$ results in a higher breakdown strength of the nanocomposites compared to nanocomposites containing $\mathrm{MgAl}_{2} \mathrm{O}_{4}$. Meanwhile, nanocomposites containing $\mathrm{CaCO}_{3} \mathrm{~T}$ possess the highest breakdown strength among the systems considered. Possible mechanisms governing these dielectric property changes under alternating current and direct current electric fields are discussed.
\end{abstract}

Index Terms-Nanocomposites, polypropylene, magnesium aluminate, calcium carbonate, dielectric breakdown.

\section{INTRODUCTION}

$\mathrm{P}$ OLYMERIC materials have been widely used as high voltage cable insulation due to their low dielectric constant, low cost, and excellent mechanical flexibility [1]. Cross-linked polyethylene (XLPE), for example, is a commonly used insulation material in high voltage alternating current (HVAC) and high voltage direct current (HVDC) cables. However, XLPE has its drawbacks, such as negatively affected long-term performance due to the presence of crosslinking by-products, poor thermal conductivity at technologically relevant temperatures due to its low

Manuscript received November 29, 2020; revised March 3, 2021; accepted April 26, 2021. Date of publication Month XX, 2021; date of current version Month XX, 2021. (Corresponding author: Kwan Yiew Lau.)

Aizat Azmi, Kwan Yiew Lau, Noor Azlinda Ahmad, Zulkurnain AbdulMalek, and Chee Wei Tan are with the School of Electrical Engineering, Universiti Teknologi Malaysia, Johor Bahru 81310, Malaysia (e-mail: aizat.azmi.1987@gmail.com; kwanyiew@utm.my; noorazlinda@utm.my; zulkurnain@utm.my; cheewei@utm.my)

Kuan Yong Ching is with the School of Foundation, University of Reading Malaysia, Iskandar Puteri 79200, Malaysia (e-mail: k.y.ching@ @eading.edu.my).

Alun S. Vaughan is with the Electronics and Computer Science, University of Southampton, Southampton SO17 1BJ, UK (asv@ecs.soton.ac.uk).

Digital Object Identifier melting temperature and problematical recycling due to its thermoset nature as a consequence of the crosslinking process [2].

In view of the aforementioned issues, polypropylene (PP) has recently been highlighted as a potential alternative to XLPE. PP, which is a thermoplastic material, can be recycled with ease compared to XLPE. Furthermore, PP has additional benefits of having a higher melting temperature (commonly above $150{ }^{\circ} \mathrm{C}$ ), low dielectric constant, reduced space charge accumulation and high volume resistivity compared to XLPE [3], albeit that at room temperature, its thermal conductivity falls below that of XLPE. To date, many experimental results have demonstrated that appropriately produced PP can provide good mechanical flexibility, high melting temperature, reduced space charge accumulation, and high breakdown strength [4-6]. For example, Hoiser et al. [7] discovered that different PP blend compositions changed the mechanical flexibility, breakdown strength, and thermal characteristics of the materials. Green et al. [8] reported that blending $50 \%$ of isotactic PP with $50 \%$ of a propyleneethylene copolymer resulted in an optimal composition that improved the electrical and mechanical properties of the material. Significantly, Andritsch et al. [2] reported that propylene-based blends could exhibit excellent electrical performance when extruded as a mini-cable.

In line with the development of PP insulation, further experimental studies on PP nanocomposites revealed that the addition of nanofillers to PP could potentially enhance the dielectric properties of the resulting systems [5, 9, 10]. For example, Zhou et al. [5] demonstrated that adding magnesium oxide $(\mathrm{MgO})$, titanium dioxide $\left(\mathrm{TiO}_{2}\right)$, zinc oxide $(\mathrm{ZnO})$, and aluminum oxide $\left(\mathrm{Al}_{2} \mathrm{O}_{3}\right)$ to $\mathrm{PP}$ altered the dielectric permittivity, DC volume resistivity, and space charge behavior of PP nanocomposites in favor of dielectric enhancements. Li et al. [9], on the other hand, found that the addition of graphene to PP increased the dielectric permittivity of PP nanocomposites. However, many other reports have shown contradictory results, where the inclusion of single-metal oxide nanofillers has also resulted in degraded breakdown performance [11-13].

Recently, multi-element oxide nanofillers have been shown to have a compact structure with supreme thermal, mechanical, and electrical properties compared to single-metal oxide nanofillers [14, 15]. For instance, Clinard et al. [16] demonstrated that a magnesium aluminate $\left(\mathrm{MgAl}_{2} \mathrm{O}_{4}\right)$ nanofiller exhibited improved mechanical strength compared to standalone $\mathrm{MgO}$ and $\mathrm{Al}_{2} \mathrm{O}_{3}$ nanofillers. In addition, appropriately controlled sintering 
temperatures of $\mathrm{MgAl}_{2} \mathrm{O}_{4}$ could also improve the dielectric properties of the material [17]. Rupaal [18] attributed the improved dielectric properties of $\mathrm{MgAl}_{2} \mathrm{O}_{4}$ to the strong ionic bonding between cations of $\mathrm{Mg}$ and $\mathrm{Al}$ and anions of oxygen in $\mathrm{MgAl}_{2} \mathrm{O}_{4}$, which is specific to this material system. Meanwhile, calcium carbonate $\left(\mathrm{CaCO}_{3}\right)$ nanofiller, a multi-element oxide nanofiller possessing a high specific surface area, contributed to improved thermal properties of both polystyrene- [19] and polypropylenebased nanocomposites [20] with just a few weight percent (wt\%) of its addition to the materials. Avella et al. [21] demonstrated that adding $\mathrm{CaCO}_{3}$ to isotactic polypropylene (iPP) enhanced the thermal stability of the material compared to unfilled iPP. Similar findings were reported by Morel et al. [22] and Gao et al. [23], where the introduction of $\mathrm{CaCO}_{3}$ improved the thermal stability of poly(vinylidene fluoride) (PVDF) and poly(ethylene terephthalate) (PET) nanocomposites, respectively.

Although the use of multi-element oxide nanofillers in nanocomposites seems promising, the application of such nanofillers is less well explored from the perspective of nanocomposite dielectrics. As far as we are aware, very few systematic investigations have been conducted on the dielectric effects of multi-element oxide nanofillers, especially when added to PP, albeit that the benefits of using multi-element oxide nanofillers in improving the breakdown strength of nanocomposites have been reported elsewhere [24, 25]. Therefore, different types of multi-element oxide nanofillers, i.e., $\mathrm{MgAl}_{2} \mathrm{O}_{4}$, $\mathrm{CaCO}_{3}$, and surface-modified $\mathrm{CaCO}_{3}$ nanofillers, were considered in the current work, to determine their effects on the structure and dielectric properties of PP-based nanocomposites. Furthermore, reported studies of PP involved the introduction of a distinct rubbery phase into isotactic PP to reduce the overall flexural modulus of the final blend; in contrast, here, we considered the effect of introducing a PP impact copolymer that possessed lowered flexural modulus to serve as an impact modifier for isotactic PP. The rationale behind the selection of a such a PP blend was to minimize phase separation - a challenge commonly encountered by the introduction of a distinct rubbery phase into PP [2] - between the two polymers, such that any specific effects brought about by the addition of the multi-element oxide nanofillers to the base PP could be better examined.

\section{EXPERIMENTAL}

\section{A. Materials}

The polymer matrix used in this study was a blend of PP composed of $50 \mathrm{wt} \%$ of a PP homopolymer (isotactic, grade TITANPRO $6531 \mathrm{M}$ ) and $50 \mathrm{wt} \%$ of a PP impact copolymer (grade TITANPRO SM340), obtained from Lotte Chemical Titan. Meanwhile, $\mathrm{MgAl}_{2} \mathrm{O}_{4}$ (with a manufacturer-quoted particle size of less than $50 \mathrm{~nm}$, obtained from Sigma Aldrich) and $\mathrm{CaCO}_{3}$ (with a manufacturer-quoted particle size of $15-40 \mathrm{~nm}$, obtained from SkySpring Nanomaterials) were used as nanofillers. In addition, another batch of $\mathrm{CaCO}_{3}$, which was surface modified for compatibility with PP (as claimed by the manufacturer), was obtained from the same supplier (SkySpring Nanomaterials, with a manufacturer-quoted particle size of 15-40 nm). This surfacemodified $\mathrm{CaCO}_{3}$ is denoted as $\mathrm{CaCO}_{3} \mathrm{~T}$ hereafter. Three nanofiller loading levels were chosen, i.e., $1 \mathrm{wt} \%, 2 \mathrm{wt} \%$, and $5 \mathrm{wt} \%$.

\section{1) Preparation of Nanocomposites}

$\mathrm{PP}$ nanocomposites containing $\mathrm{MgAl}_{2} \mathrm{O}_{4}, \mathrm{CaCO}_{3}$, and $\mathrm{CaCO}_{3} \mathrm{~T}$ nanofillers were prepared using a Brabender melt mixer. The rotational speed, temperature, and duration were set at $50 \mathrm{rpm}$, $180^{\circ} \mathrm{C}$, and $10 \mathrm{~min}$, respectively. To produce thin film specimens $100 \mu \mathrm{m}$ in thickness, samples were melt-pressed using a hydraulic laboratory press at a temperature of $180{ }^{\circ} \mathrm{C}$. The melt-pressed samples were then left to cool down naturally under ambient laboratory conditions. For convenience, all prepared samples are denoted using the general notation " $\mathrm{P} / \mathrm{F} / \mathrm{A}$ ". In this, $\mathrm{P}$ refers to the polymer, F signifies the nanofiller, and A represents the amount of nanofiller, as indicated in Table 1.

\section{B. Characterization}

Thermogravimetric analysis (TGA) was carried out to investigate the mass changes of nanofillers and nanocomposites as a function of temperature. These experiments were conducted under a nitrogen atmosphere from 30 to $900{ }^{\circ} \mathrm{C}$ at a scan rate of $10^{\circ} \mathrm{C} \mathrm{min}{ }^{-1}$. For each measurement, $5 \mathrm{mg}$ of sample was used. A Perkin Elmer TGA 4000 instrument was employed for these measurements.

Fourier transform infrared (FTIR) spectroscopy (spectrometer model IRTracer-100: Shimadzu) was used to obtain chemical information pertaining to the materials. Nanopowders and thin-film samples (nominally $100 \mu \mathrm{m}$ in thickness) were characterized for this purpose and the spectral data were collected from 500 to $4000 \mathrm{~cm}^{-1}$ over 8 scans at $4 \mathrm{~cm}^{-1}$ resolution.

The thermal behavior of the nanocomposites was examined by means of a Perkin Elmer DSC6 differential scanning calorimeter (DSC) in a nitrogen atmosphere. For each measurement, $5 \mathrm{mg}$ of the sample was prepared and sealed in an aluminum pan. High purity indium, with a known melting temperature of $156.6{ }^{\circ} \mathrm{C}$ and melting enthalpy of $28.45 \mathrm{~J} \mathrm{~g} \mathrm{~g}^{-1}$, was used for calibration purposes. During each DSC scan, the sample was first heated from 60 to $180{ }^{\circ} \mathrm{C}$ at a scan rate of $10{ }^{\circ} \mathrm{C} \mathrm{min}-1$ to characterize its melting behavior. Next, the sample was cooled from 180 to $60{ }^{\circ} \mathrm{C}$ at a scan rate of $10{ }^{\circ} \mathrm{C} \mathrm{min}{ }^{-1}$ to determine its cooling behavior. Perkin Elmer's Pyris software was used to analyze the resulting data.

Scanning electron microscopy (SEM) was carried out by means of an Hitachi TM3000 SEM, to investigate the morphological structure of the nanocomposites and to determine the dispersion state of the nanofillers within the PP. Generally, a $15 \mathrm{kV}$ voltage and a $38 \mathrm{~mm}$ working distance were

Table 1. Sample designation.

\begin{tabular}{|c|c|c|c|}
\hline Sample (P/F/A) & Polymer (P) & Filler (F) & Amount (A) \\
\hline $\mathrm{PP} / 0 / 0$ & PP & No nanofiller & $0 \mathrm{wt} \%$ \\
\hline $\mathrm{PP} / \mathrm{MgAl}_{2} \mathrm{O}_{4} / 1$ & PP & $\mathrm{MgAl}_{2} \mathrm{O}_{4}$ & $1 \mathrm{wt} \%$ \\
\hline $\mathrm{PP} / \mathrm{MgAl}_{2} \mathrm{O}_{4} / 2$ & PP & $\mathrm{MgAl}_{2} \mathrm{O}_{4}$ & $2 \mathrm{wt} \%$ \\
\hline $\mathrm{PP} / \mathrm{MgAl}_{2} \mathrm{O}_{4} / 5$ & PP & $\mathrm{MgAl}_{2} \mathrm{O}_{4}$ & $5 \mathrm{wt} \%$ \\
\hline $\mathrm{PP} / \mathrm{CaCO}_{3} / 1$ & $\mathrm{PP}$ & $\mathrm{CaCO}_{3}$ & $1 \mathrm{wt} \%$ \\
\hline $\mathrm{PP} / \mathrm{CaCO}_{3} / 2$ & PP & $\mathrm{CaCO}_{3}$ & $2 \mathrm{wt} \%$ \\
\hline $\mathrm{PP} / \mathrm{CaCO}_{3} / 5$ & $\mathrm{PP}$ & $\mathrm{CaCO}_{3}$ & $5 \mathrm{wt} \%$ \\
\hline $\mathrm{PP} / \mathrm{CaCO}_{3} \mathrm{~T} / 1$ & PP & $\mathrm{CaCO}_{3} \mathrm{~T}$ & $1 \mathrm{wt} \%$ \\
\hline $\mathrm{PP} / \mathrm{CaCO}_{3} \mathrm{~T} / 2$ & PP & $\mathrm{CaCO}_{3} \mathrm{~T}$ & $2 \mathrm{wt} \%$ \\
\hline $\mathrm{PP} / \mathrm{CaCO}_{3} \mathrm{~T} / 5$ & PP & $\mathrm{CaCO}_{3} \mathrm{~T}$ & $5 \mathrm{wt} \%$ \\
\hline
\end{tabular}


employed. Prior to SEM, the samples were immersed in liquid nitrogen and fractured. The fracture surfaces of the samples were then sputter-coated with platinum using a Quorum SC 7620 automated platinum sputter coater at 15-18 mA for $1 \mathrm{~min}$ to minimize charge accumulation and poor resolution during SEM.

Dielectric response measurements were conducted to determine the dielectric constant, $\varepsilon_{r}$, of film samples prepared as above. A Gamry Instruments Interface 1000 with a Tettex 2914 test cell for solid insulations $(25 \mathrm{~mm}$ radius inner guarded electrode) was used. Under the low noise optimization setting, a $1 \mathrm{~V}$ AC signal was applied over a frequency range of $100 \mathrm{~Hz}$ to $100 \mathrm{kHz}$ at 20 points per decade.

AC and DC breakdown tests were performed using a dielectric strength tester. The tests were carried out based on the guidelines set out in the American Society for Testing and Materials (ASTM) D149. The thickness of each test sample was nominally $100 \mu \mathrm{m}$. The sample was sandwiched between two $6.3 \mathrm{~mm}$ diameter steel ball electrodes and immersed in mineral oil (to prevent surface discharge). AC and DC step voltages of $1 \mathrm{kV}$ every $20 \mathrm{~s}$ and $2 \mathrm{kV}$ every $20 \mathrm{~s}$, respectively, were applied until breakdown. 15 breakdown points were recorded for each sample type and analyzed using the two-parameter Weibull statistical distribution method.

\section{RESULTS AND DISCUSSION}

\section{A. Thermogravimetric Analysis}

From TGA of the $\mathrm{MgAl}_{2} \mathrm{O}_{4}$ nanopowder presented in Figure 1a, the mass loss can be discussed in terms of two processes. Firstly, a drastic mass change occurs at temperatures between 30 and $100{ }^{\circ} \mathrm{C}$. This is attributed to the removal of physically adsorbed water [26]. Secondly, a noticeable variation in mass can be observed between 100 and $500{ }^{\circ} \mathrm{C}$. This is likely associated with surface dehydration of the nanofiller. Thereafter, no significant mass changes are observed.

For the $\mathrm{CaCO}_{3}$ nanopowder, a total mass reduction of about $40 \%$ over the complete temperature range can be observed from TGA (see Figure 1b). The mass loss process that occurs over the temperature range $\sim 600-800{ }^{\circ} \mathrm{C}$ is related to the transition from the carbonate to the oxide, with the consequent loss of $\mathrm{CO}_{2}$ [27]. While the $\mathrm{CaCO}_{3} \mathrm{~T}$ nanopowder exhibits an equivalent transition above $600{ }^{\circ} \mathrm{C}$ (see Figure 1c), the lower temperature process at about $300{ }^{\circ} \mathrm{C}$ is related to decomposition of the stearic acid surface modifier used by the manufacturer; it has previously been reported that stearic acid decomposes at temperatures around $360{ }^{\circ} \mathrm{C}$ [28]. From the known specific surface area of the nanofiller, this mass loss equates to a particle coating thickness of $\sim 1 \mathrm{~nm}$.

TGA curves obtained from all the investigated nanocomposite samples are shown in Figure 2. The reference, unfilled PP is characterized by one stage of thermal decomposition, which begins at $\sim 290^{\circ} \mathrm{C}$ (see the upper inset in Figure 2a). This is attributed to the decomposition of the PP matrix. Meanwhile, all nanocomposites containing $\mathrm{MgAl}_{2} \mathrm{O}_{4}$ evince a loss of mass as early as $\sim 50{ }^{\circ} \mathrm{C}$ (compare the plots in the upper inset in Figure 2a). This aligns with the TGA analysis in Figure 1a and is attributed to the removal of physically adsorbed water from the $\mathrm{MgAl}_{2} \mathrm{O}_{4}$. For all nanocomposites

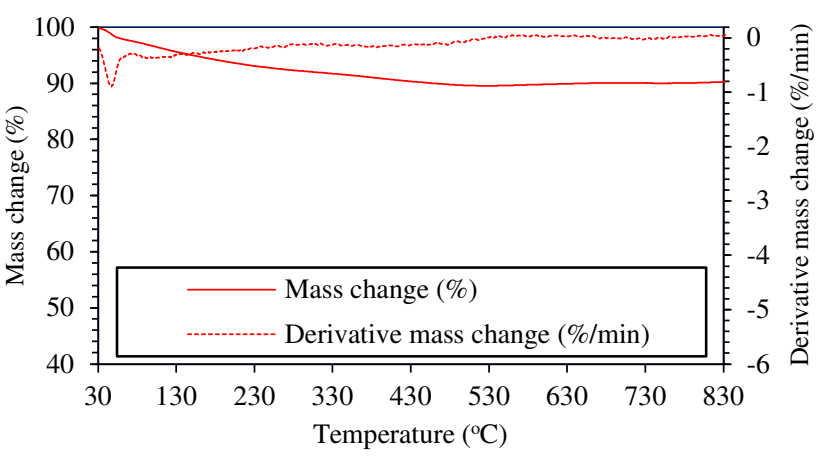

(a)

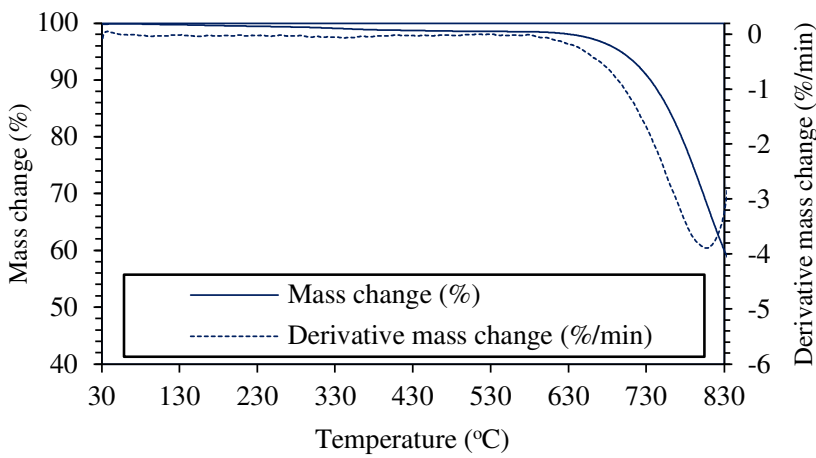

(b)

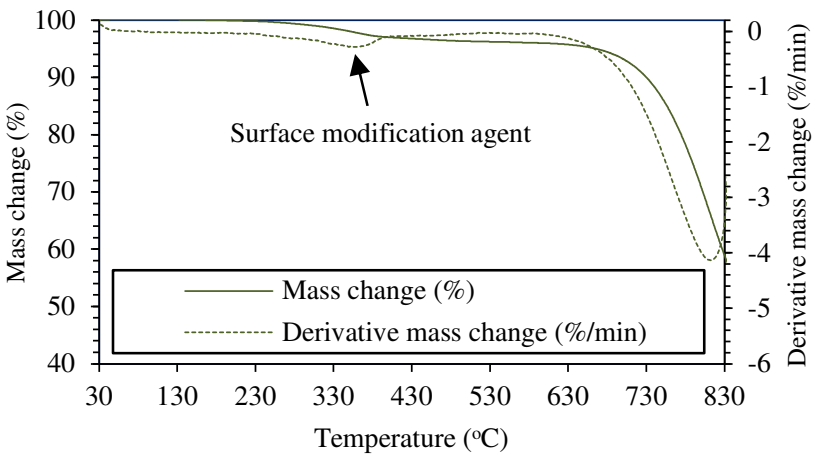

(c)

Figure 1. TGA curve of (a) $\mathrm{MgAl}_{2} \mathrm{O}_{4}$, (b) $\mathrm{CaCO}_{3}$, (c) $\mathrm{CaCO}_{3} \mathrm{~T}$ nanopowders.

containing $\mathrm{CaCO}_{3}$ and $\mathrm{CaCO}_{3} \mathrm{~T}$, this early thermal degradation is less apparent (see the upper insets in Figures $2 \mathrm{~b}$ and $2 \mathrm{c}$ ). Nevertheless, all nanocomposites containing $\mathrm{CaCO}_{3}$ and $\mathrm{CaCO}_{3} \mathrm{~T}$ exhibit an additional stage of thermal decomposition at $\sim 600{ }^{\circ} \mathrm{C}$ (see the lower insets in Figures $2 \mathrm{~b}$ and $2 \mathrm{c}$ ), indicating thermal decomposition of the $\mathrm{CaCO}_{3}$ and $\mathrm{CaCO}_{3} \mathrm{~T}$ nanofillers [28]. This is, again, in line with the mass changes results obtained from the $\mathrm{CaCO}_{3}$ and $\mathrm{CaCO}_{3} \mathrm{~T}$ nanopowders shown in Figures $1 \mathrm{~b}$ and $1 \mathrm{c}$.

The degradation process of the samples can be characterized from the temperature that corresponds to $5 \%$ mass loss $\left(T_{5 \%}\right)$ and $50 \%$ mass loss $\left(T_{50 \%}\right)$, as determined by TGA, where analysis of mass changes in this temperature region is important to determine the thermal stability of the material. From Table 2, the unfilled PP loses 5 and $50 \%$ of its mass at $337{ }^{\circ} \mathrm{C}$ and $400{ }^{\circ} \mathrm{C}$, respectively. Significantly, all the nanocomposites possess higher $T_{5 \%}$ and $T_{50 \%}$ values than the unfilled PP, indicating improved thermal stability of the nanocomposites over the unfilled PP. For example, nanocomposites containing 1 wt $\%$ of $\mathrm{MgAl}_{2} \mathrm{O}_{4}$ have increased $T_{5 \%}$ and $T_{50 \%}$ values of 
$402{ }^{\circ} \mathrm{C}$ and $450{ }^{\circ} \mathrm{C}$, respectively, compared to the unfilled PP. The increase is more apparent at higher nanofiller loading levels. Similarly, nanocomposites containing $\mathrm{CaCO}_{3}$ and $\mathrm{CaCO}_{3} \mathrm{~T}$ possess higher $T_{5 \%}$ and $T_{50 \%}$ values than the unfilled $\mathrm{PP}$, albeit that the values are lower than in the nanocomposites containing $\mathrm{MgAl}_{2} \mathrm{O}_{4}$.

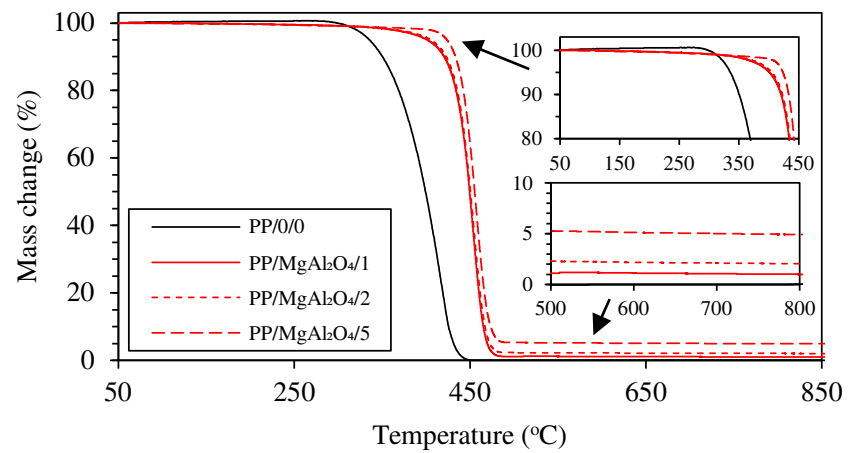

(a)

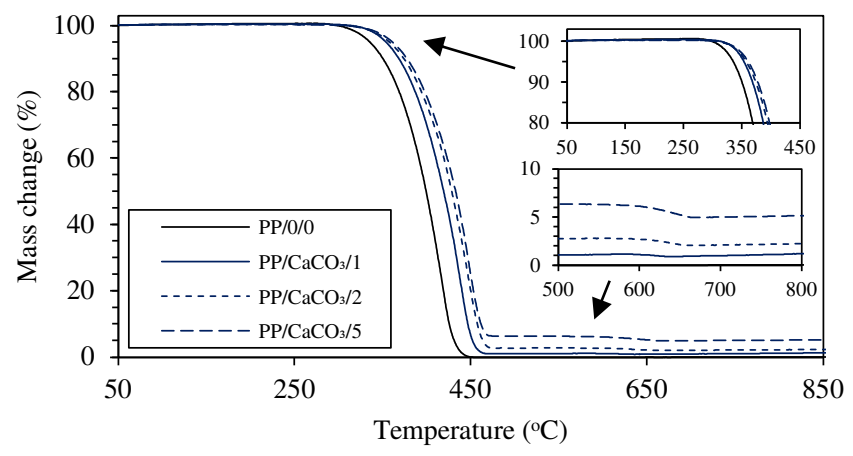

(b)

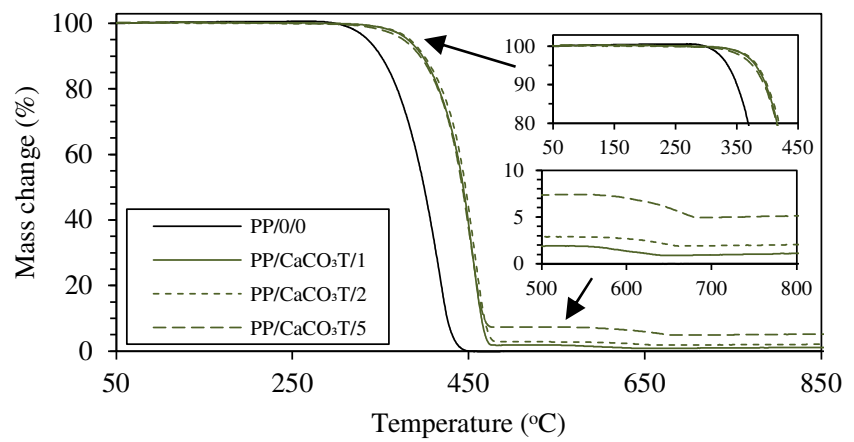

(c)

Figure 2. TGA curve of nanocomposites containing (a) $\mathrm{MgAl}_{2} \mathrm{O}_{4}$, (b) $\mathrm{CaCO}_{3}$, (c) $\mathrm{CaCO}_{3} \mathrm{~T}$.

Table 2. The thermal stability of nanocomposites corresponds to $5 \%$ mass loss $\left(T_{5 \%}\right)$ and $50 \%$ mass loss $\left(T_{50 \%}\right)$ from TGA curves.

\begin{tabular}{lll}
\hline Samples & $\mathbf{T}_{\mathbf{5} \%}$ & $\mathbf{T}_{\mathbf{5 0} \%}$ \\
\hline $\mathrm{PP} / 0 / 0$ & 337 & 400 \\
$\mathrm{PP} / \mathrm{MgAl}_{2} \mathrm{O}_{4} / 1$ & 402 & 450 \\
$\mathrm{PP} / \mathrm{MgAl}_{2} \mathrm{O}_{4} / 2$ & 406 & 451 \\
$\mathrm{PP} / \mathrm{MgAl}_{2} \mathrm{O}_{4} / 5$ & 425 & 456 \\
$\mathrm{PP} / \mathrm{CaCO}_{3} / 1$ & 356 & 420 \\
$\mathrm{PP} / \mathrm{CaCO}_{3} / 2$ & 360 & 429 \\
$\mathrm{PP} / \mathrm{CaCO}_{3} / 5$ & 363 & 433 \\
$\mathrm{PP} / \mathrm{CaCO}_{3} \mathrm{~T} / 1$ & 382 & 444 \\
$\mathrm{PP} / \mathrm{CaCO}_{3} \mathrm{~T} / 2$ & 385 & 447 \\
$\mathrm{PP} / \mathrm{CaCO}_{3} \mathrm{~T} / 5$ & 378 & 443 \\
\hline
\end{tabular}

\section{B. Fourier Transform Infrared Spectroscopy}

Figure 3 presents FTIR spectra of $\mathrm{MgAl}_{2} \mathrm{O}_{4}, \mathrm{CaCO}_{3}$, and $\mathrm{CaCO}_{3} \mathrm{~T}$ nanopowders. Of note, $\mathrm{MgAl}_{2} \mathrm{O}_{4}$ exhibits absorption bands at $686 \mathrm{~cm}^{-1}$ and $526 \mathrm{~cm}^{-1}$, representing the stretching vibration of $\mathrm{MgO}_{4}$ tetrahedral and $\mathrm{AlO}_{6}$ octahedral groups, respectively. In addition, a weak absorption band at about $3400 \mathrm{~cm}^{-1}$ can be observed, indicating the presence of surface hydroxyl groups and related water molecules on $\mathrm{MgAl}_{2} \mathrm{O}_{4}$ [29]. This aligns with the TGA results discussed above. Meanwhile, $\mathrm{CaCO}_{3}$ exhibits characteristic absorption bands at $1418 \mathrm{~cm}^{-1}$, $873 \mathrm{~cm}^{-1}$ and $707 \mathrm{~cm}^{-1}$, which are indicative of the fundamental bands of the calcite structure and asymmetrical stretching vibration peaks of $\mathrm{O}-\mathrm{C}-\mathrm{O}$. Similar absorption characteristics can be observed for $\mathrm{CaCO}_{3} \mathrm{~T}$.

The FTIR spectra of the unfilled PP and the nanocomposites containing $5 \mathrm{wt} \%$ of $\mathrm{MgAl}_{2} \mathrm{O}_{4}, \mathrm{CaCO}_{3}$, and $\mathrm{CaCO}_{3} \mathrm{~T}$ are shown in Figure 4. Similar FTIR spectra were obtained from nanocomposites containing 1 and $2 \mathrm{wt} \%$ of the respective $\mathrm{MgAl}_{2} \mathrm{O}_{4}, \mathrm{CaCO}_{3}$, and $\mathrm{CaCO}_{3} \mathrm{~T}$ and, hence, are not shown for brevity. For the unfilled PP, the absorption peaks between $2836 \mathrm{~cm}^{-1}$ and $2950 \mathrm{~cm}^{-1}$ are indicative of the stretching vibration of methyl and methylene groups, while the absorption peaks from $844 \mathrm{~cm}^{-1}$ to $1458 \mathrm{~cm}^{-1}$ reflect the bending vibration of methyl and methylene groups. By adding $\mathrm{MgAl}_{2} \mathrm{O}_{4}$ to $\mathrm{PP}$, a characteristic absorption peak of $\mathrm{MgAl}_{2} \mathrm{O}_{4}$ at $686 \mathrm{~cm}^{-1}$ (as discussed previously) can be noticed, and the peak becomes more apparent with increasing $\mathrm{MgAl}_{2} \mathrm{O}_{4}$ loading (not shown for brevity), albeit that the absorption band at about $3400 \mathrm{~cm}^{-1}$

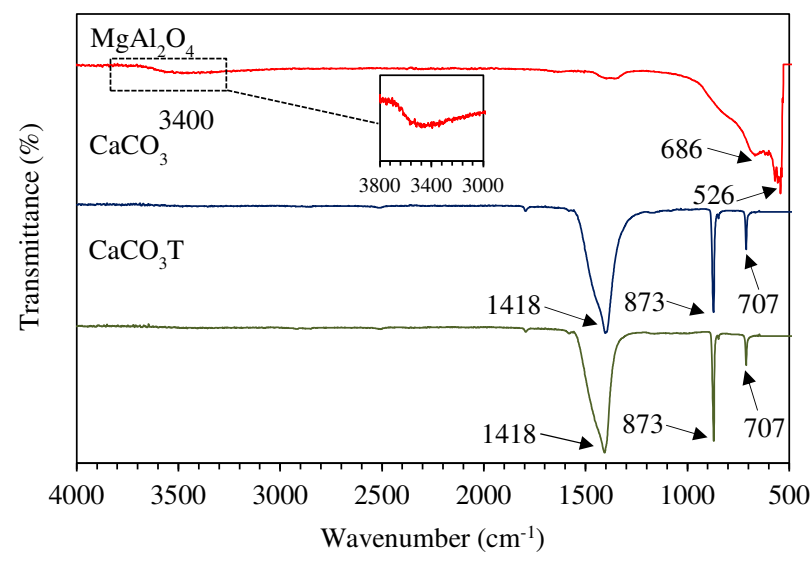

Figure 3. FTIR spectra of $\mathrm{MgAl}_{2} \mathrm{O}_{4}, \mathrm{CaCO}_{3}$, and $\mathrm{CaCO}_{3} \mathrm{~T}$ nanopowders.

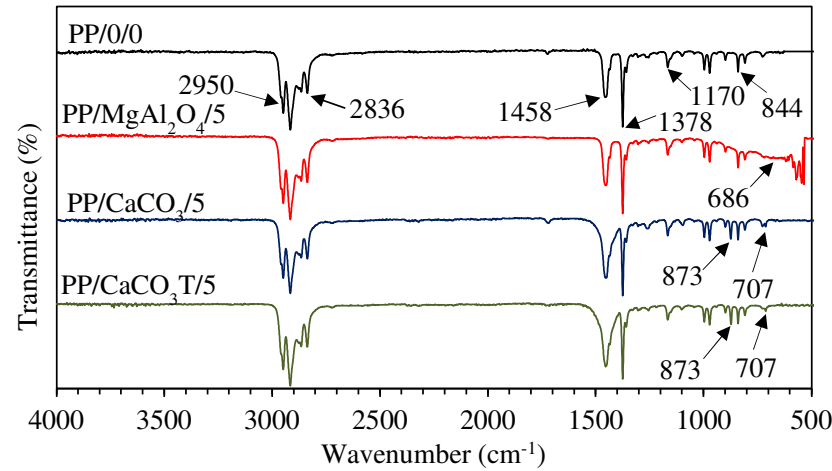

Figure 4. FTIR spectra comparing unfilled $\mathrm{PP}$ and nanocomposites containing $5 \mathrm{wt} \%$ of $\mathrm{MgAl}_{2} \mathrm{O}_{4}, \mathrm{CaCO}_{3}$, and $\mathrm{CaCO}_{3} \mathrm{~T}$. 
cannot be clearly observed. Meanwhile, the addition of $\mathrm{CaCO}_{3}$ and $\mathrm{CaCO}_{3} \mathrm{~T}$ to PP results in additional absorption bands that belong to the nanofillers at $873 \mathrm{~cm}^{-1}$ and $707 \mathrm{~cm}^{-1}$ (as discussed previously). These demonstrate the successful addition of $\mathrm{MgAl}_{2} \mathrm{O}_{4}, \mathrm{CaCO}_{3}$, and $\mathrm{CaCO}_{3} \mathrm{~T}$ to $\mathrm{PP}$.

\section{Differential Scanning Calorimetry}

DSC melting traces comparing unfilled PP with nanocomposites containing $\mathrm{MgAl}_{2} \mathrm{O}_{4}, \mathrm{CaCO}_{3}$, and $\mathrm{CaCO}_{3} \mathrm{~T}$ are shown in Figure 5a. The peak melting temperature for all samples is approximately $162{ }^{\circ} \mathrm{C}$, which corresponds to the fusion peak of the $\alpha$-crystal form of PP [5]. The similar DSC melting behaviors of all investigated samples indicates that the addition of $\mathrm{MgAl}_{2} \mathrm{O}_{4}, \mathrm{CaCO}_{3}$, and $\mathrm{CaCO}_{3} \mathrm{~T}$ to PP does not affect the distribution of lamellar thicknesses present in each material. In addition, a secondary melting peak at $\sim 148{ }^{\circ} \mathrm{C}$ is evident, which is indicative of the presence of $\beta$-crystals [5]. This feature is more apparent for nanocomposites containing increasing amounts of $\mathrm{CaCO}_{3}$ and $\mathrm{CaCO}_{3} \mathrm{~T}$. Consequently, we conclude that the addition of $\mathrm{CaCO}_{3}$ and $\mathrm{CaCO}_{3} \mathrm{~T}$ to $\mathrm{PP}$ promotes the generation of $\beta$-crystals (increased magnitude of the secondary melting peak at $\sim 148{ }^{\circ} \mathrm{C}$ ). Meanwhile, the samples' DSC cooling traces are shown in Figure 5b. All samples are characterized by a crystallization temperature $\left(T_{c}\right)$ close to $118{ }^{\circ} \mathrm{C}$, except for nanocomposites containing $\mathrm{MgAl}_{2} \mathrm{O}_{4}$, where $T_{c}$ can be seen to increase with increasing amounts of $\mathrm{MgAl}_{2} \mathrm{O}_{4}$. This implies that $\mathrm{MgAl}_{2} \mathrm{O}_{4}$ acts as a nucleating agent and modifies the gross matrix morphology [30].

\section{Scanning Electron Microscopy}

Figure 6a shows an SEM micrograph of the unfilled PP. The structure of this system is not well revealed; rather, the surface appearance is dominated by fractography features, as explained elsewhere [24]. Nevertheless, this does imply the absence of significant phase separation, indicating good miscibility between the two blend components. Figures $6 \mathrm{~b}, 6 \mathrm{c}$, and $6 \mathrm{~d}$ show SEM images of fracture surfaces through nanocomposites containing 1, 2, and $5 \mathrm{wt} \%$ of $\mathrm{MgAl}_{2} \mathrm{O}_{4}$. Good dispersion of $\mathrm{MgAl}_{2} \mathrm{O}_{4}$ down to $\sim 100 \mathrm{~nm}$ can be observed (arrowed), albeit

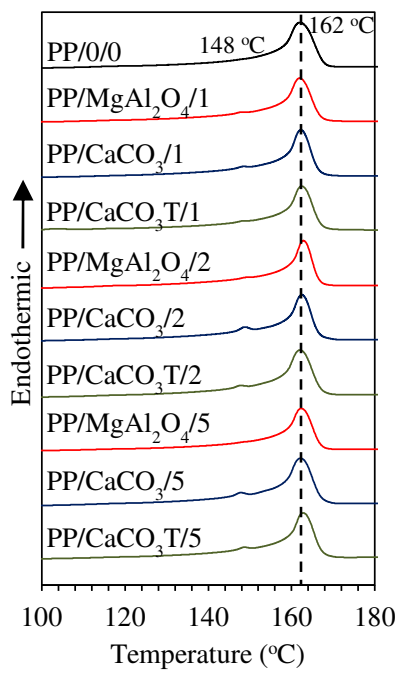

(a)

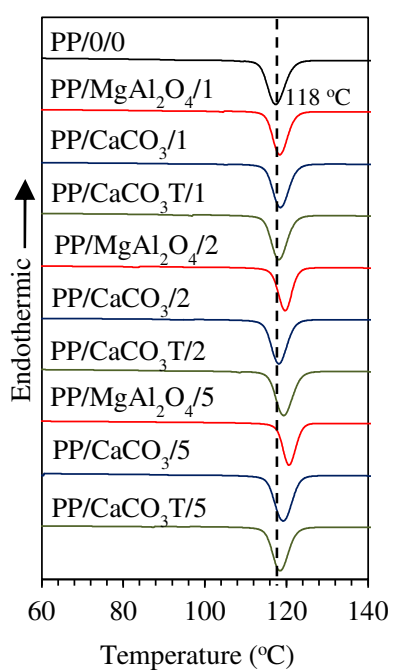

(b)
Figure 5. DSC (a) melting traces, (b) cooling traces comparing $\mathrm{PP} / 0 / 0$ with nanocomposites containing $\mathrm{MgAl}_{2} \mathrm{O}_{4}, \mathrm{CaCO}_{3}$, and $\mathrm{CaCO}_{3} \mathrm{~T}$. that some agglomeration of $\mathrm{MgAl}_{2} \mathrm{O}_{4}$ is present (circled); the agglomeration appears more prevalent with increasing $\mathrm{MgAl}_{2} \mathrm{O}_{4}$ loading, leading to clusters up to several micrometers in size. Figures 6e, $6 \mathrm{f}$, and $6 \mathrm{~g}$ show the SEM morphology of nanocomposites containing 1, 2, and $5 \mathrm{wt} \%$ of $\mathrm{CaCO}_{3}$, respectively, while Figures $6 \mathrm{~h}, 6 \mathrm{i}$, and $6 \mathrm{j}$ contain equivalent images obtained from nanocomposites containing 1, 2, and $5 \mathrm{wt} \%$ of $\mathrm{CaCO}_{3} \mathrm{~T}$, respectively. Again, good dispersion of $\mathrm{CaCO}_{3}$ and $\mathrm{CaCO}_{3} \mathrm{~T}$ down to $\sim 100 \mathrm{~nm}$ can be observed. With modified nanofiller surface, better $\mathrm{CaCO}_{3} \mathrm{~T}$ dispersion in PP can be observed compared to $\mathrm{MgAl}_{2} \mathrm{O}_{4}$ and $\mathrm{CaCO}_{3}$.

The agglomeration of nanoparticles is well known to be one of the dominant factors that affects the dielectric properties of nanocomposites. SEM analysis suggests that nanocomposites containing $\mathrm{CaCO}_{3} \mathrm{~T}$ contain more small particles, compared to nanocomposites containing $\mathrm{MgAl}_{2} \mathrm{O}_{4}$ and $\mathrm{CaCO}_{3}$, but, in none of the systems is extensive agglomeration evident.

\section{E. Dielectric Response}

Figure $7 \mathrm{a}$ shows the frequency dependence of the real part of the relative permittivity, $\varepsilon$ ', of unfilled $\mathrm{PP}$ and nanocomposites containing $\mathrm{MgAl}_{2} \mathrm{O}_{4}, \mathrm{CaCO}_{3}$, and $\mathrm{CaCO}_{3} \mathrm{~T}$. The real part of the relative permittivity of the unfilled $\mathrm{PP}$ is about 2.69 throughout the measured frequency range. Meanwhile, the real relative permittivity of the nanocomposites increases with increasing nanofiller content, in line with some observations reported in the literature $[5,31]$. Nevertheless, at an equivalent nanofiller loading level, nanocomposites containing $\mathrm{CaCO}_{3} \mathrm{~T}$ possess the lowest permittivity, while nanocomposites containing $\mathrm{MgAl}_{2} \mathrm{O}_{4}$ possess the highest permittivity (e.g., compare $\mathrm{PP} / \mathrm{MgAl}_{2} \mathrm{O}_{4} / 1$, $\mathrm{PP} / \mathrm{CaCO}_{3} / 1$, and $\mathrm{PP} / \mathrm{CaCO}_{3} \mathrm{~T} / 1$ ). Significantly, the permittivity of nanocomposites containing $1 \mathrm{wt} \%$ of $\mathrm{CaCO}_{3}$ and $\mathrm{CaCO}_{3} \mathrm{~T}$ can be lower than that of the unfilled PP. Repeating these measurements showed that while for $\mathrm{PP} / \mathrm{CaCO}_{3} / 1$ the permittivity was sometimes slightly higher and sometimes slightly lower than that of the unfilled $\mathrm{PP}$, for $\mathrm{PP} / \mathrm{CaCO}_{3} \mathrm{~T} / 1$ its permittivity was always lower than that of the unfilled PP. Similar behavior has been reported elsewhere [32].

For ease of comparison, Figure 7b shows $\varepsilon$ ' of unfilled PP and nanocomposites containing $\mathrm{MgAl}_{2} \mathrm{O}_{4}, \mathrm{CaCO}_{3}$, and $\mathrm{CaCO}_{3} \mathrm{~T}$ at the specific frequency of $10 \mathrm{kHz}$ (equivalent trends were seen at $100 \mathrm{~Hz}$ ). Clearly, $\varepsilon$ ' of nanocomposites containing $\mathrm{MgAl}_{2} \mathrm{O}_{4}$ is higher than that of unfilled PP and increases monotonically with increasing $\mathrm{MgAl}_{2} \mathrm{O}_{4}$ loading level. This implies two possibilities. First, the overall increase in $\varepsilon$ ' seen in these nanocomposites is a consequence of the $\mathrm{MgAl}_{2} \mathrm{O}_{4}$ itself having a higher $\varepsilon$ ' than PP. Nevertheless, the gradual increase in $\varepsilon$ ' with decreasing frequency (see Figure 7a) suggests that interfacial relaxation processes related to the presence of water molecules (as seen by TGA) is an additional factor [26, 33, 34]. Although the addition of 2 and $5 \mathrm{wt} \%$ of $\mathrm{CaCO}_{3}$ and $\mathrm{CaCO}_{3} \mathrm{~T}$ to PP results in higher $\varepsilon$ ' values, $\varepsilon$ ' for the nanocomposites containing $\mathrm{CaCO}_{3} \mathrm{~T}$ is always lower than that of nanocomposites containing equivalent amounts of $\mathrm{CaCO}_{3}$. Significantly, the addition of $1 \mathrm{wt} \%$ of these nanofillers to PP results in a lower $\varepsilon^{\prime}$ value, compared to unfilled PP. This, according to Zha et al. [35], is related to improved interactions between nanoparticles and polymer in addition to the hindrance in the movement of entangled polymer chains. 

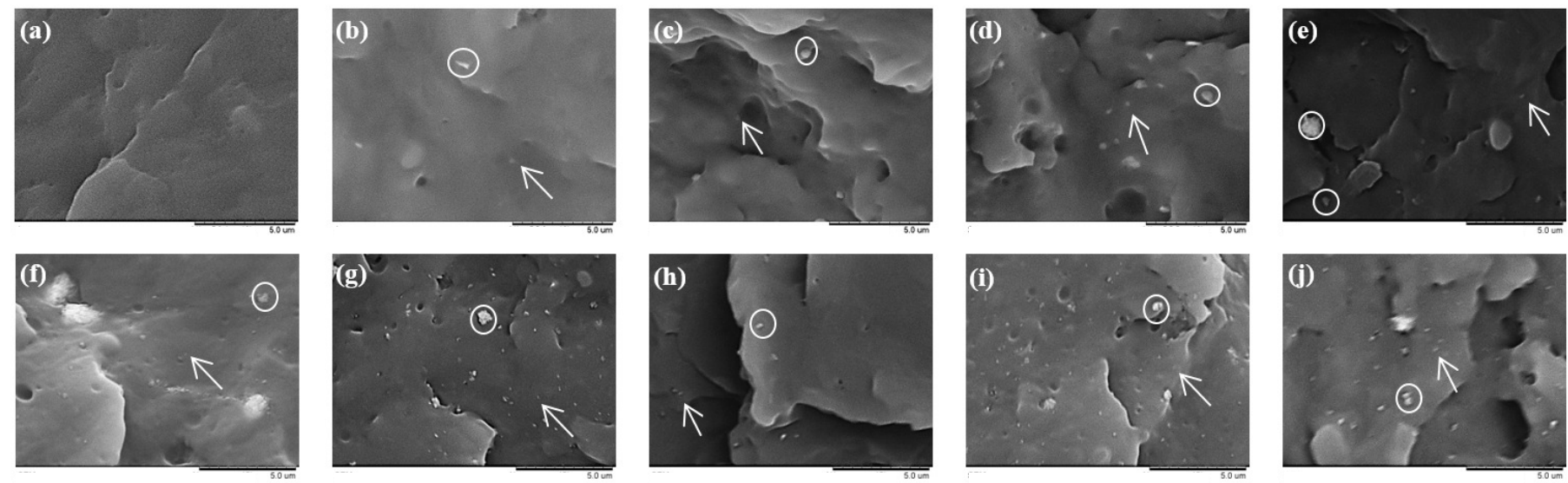

Figure 6. SEM micrograph of (a) PP/0/0, (b) $\mathrm{PP} / \mathrm{MgAl}_{2} \mathrm{O}_{4} / 1$, (c) $\mathrm{PP} / \mathrm{MgAl}_{2} \mathrm{O}_{4} / 2$, (d) $\mathrm{PP} / \mathrm{MgAl}_{2} \mathrm{O}_{4} / 5$, (e) $\mathrm{PP} / \mathrm{CaCO}_{3} / 1$, (f) $\mathrm{PP} / \mathrm{CaCO}_{3} / 2$, (g) $\mathrm{PP} / \mathrm{CaCO}_{3} / 5$, (h) $\mathrm{PP} / \mathrm{CaCO}_{3} \mathrm{~T} / 1$, (i) $\mathrm{PP} / \mathrm{CaCO}_{3} \mathrm{~T} / 2$, (j) $\mathrm{PP} / \mathrm{CaCO}_{3} \mathrm{~T} / 5$. The arrow and the circle indicate particle size of less than and larger than $100 \mathrm{~nm}$, respectively.

It is noteworthy that the values of imaginary relative permittivity, $\varepsilon$ ", obtained from all samples are very low and at the limit of the sensitivity of our equipment; these data are therefore not shown, for brevity

\section{F. Electrical Breakdown}

Figure 8a shows Weibull plots comparing AC breakdown data obtained from unfilled PP and nanocomposites containing $\mathrm{MgAl}_{2} \mathrm{O}_{4}, \mathrm{CaCO}_{3}$, and $\mathrm{CaCO}_{3} \mathrm{~T}$; derived Weibull parameters are listed in Table 3. The AC breakdown strength of the reference, unfilled PP is $112 \pm 3 \mathrm{kV} \mathrm{mm}^{-1}$. The addition of 1,2 , and $5 \mathrm{wt} \%$ of $\mathrm{MgAl}_{2} \mathrm{O}_{4}$ to PP significantly reduces the $\mathrm{AC}$ breakdown strength to $96 \pm 5 \mathrm{kV} \mathrm{mm}^{-1}, 91 \pm 4 \mathrm{kV} \mathrm{mm}^{-1}$ and $82 \pm 5 \mathrm{kV} \mathrm{mm}^{-1}$, respectively. Although the addition of 2 and $5 \mathrm{wt} \%$ of $\mathrm{CaCO}_{3}$ and $5 \mathrm{wt} \%$ of $\mathrm{CaCO}_{3} \mathrm{~T}$ to $\mathrm{PP}$ reduces the $\mathrm{AC}$ breakdown strength of the nanocomposites, the breakdown strength of these materials is higher than nanocomposites containing equivalent amounts of $\mathrm{MgAl}_{2} \mathrm{O}_{4}$. Of note, the breakdown strength of nanocomposites containing $1 \mathrm{wt} \%$ of $\mathrm{CaCO}_{3}$ and $\mathrm{CaCO}_{3} \mathrm{~T}$ appears, albeit within measurement uncertainties, slightly higher than that of the unfilled PP.

To correlate the AC breakdown behavior with the characterized structure of the materials, the following inferences are made. First, DSC cooling data imply that $\mathrm{MgAl}_{2} \mathrm{O}_{4}$ acts as a nucleating agent for PP, which will modify the gross matrix morphology of the PP by reducing the spherulite size. Previously, such changes have been correlated with increased breakdown strength [36] whereas, here, a reduction in $\mathrm{AC}$ breakdown strength is observed in systems containing $\mathrm{MgAl}_{2} \mathrm{O}_{4}$. This suggests that any morphological variations in the PP matrix are of secondary importance in determining the breakdown strength of the nanocomposites considered in this study. Second, the presence of surface hydroxyl groups and related water molecules on $\mathrm{MgAl}_{2} \mathrm{O}_{4}$ may be invoked to explain the observed reduced AC breakdown strength of these nanocomposites; our previous work on nanocomposites [26] suggests, however, that water-related effects are less influential under AC fields. Finally, since $\varepsilon^{\prime}$ of bulk $\mathrm{MgAl}_{2} \mathrm{O}_{4}$ is higher than that of PP [37], we suggest that a more relevant factor for the lower AC breakdown strength seen in nanocomposites containing $\mathrm{MgAl}_{2} \mathrm{O}_{4}$ may be local electric field intensification as a result of the permittivity mismatch between the $\mathrm{MgAl}_{2} \mathrm{O}_{4}$ and the PP. This is particularly true as agglomeration of the nanofiller becomes more prevalent with

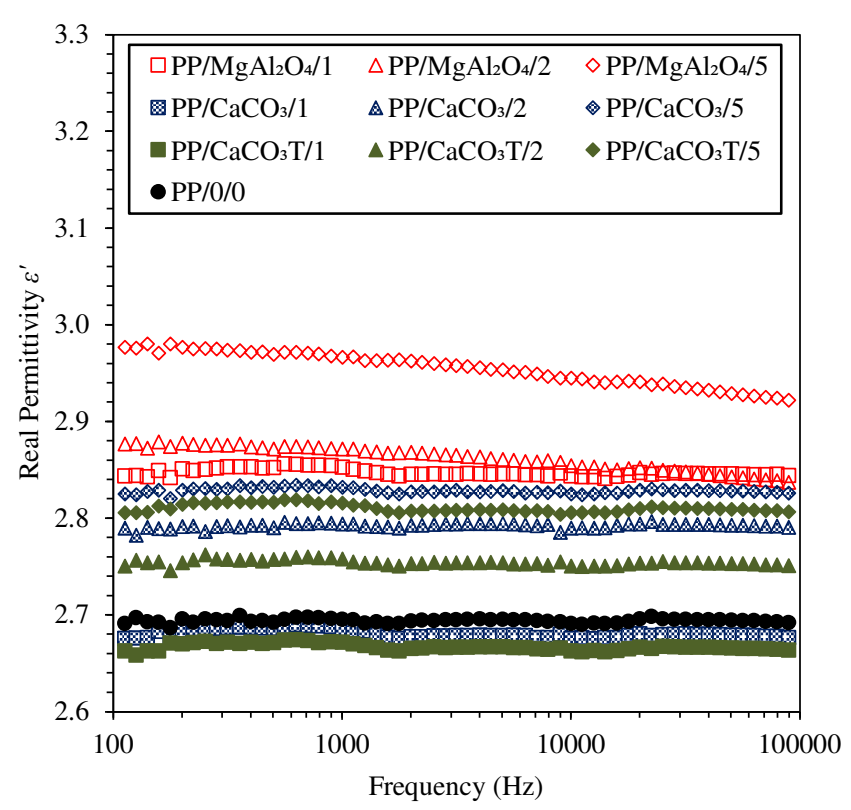

(a)

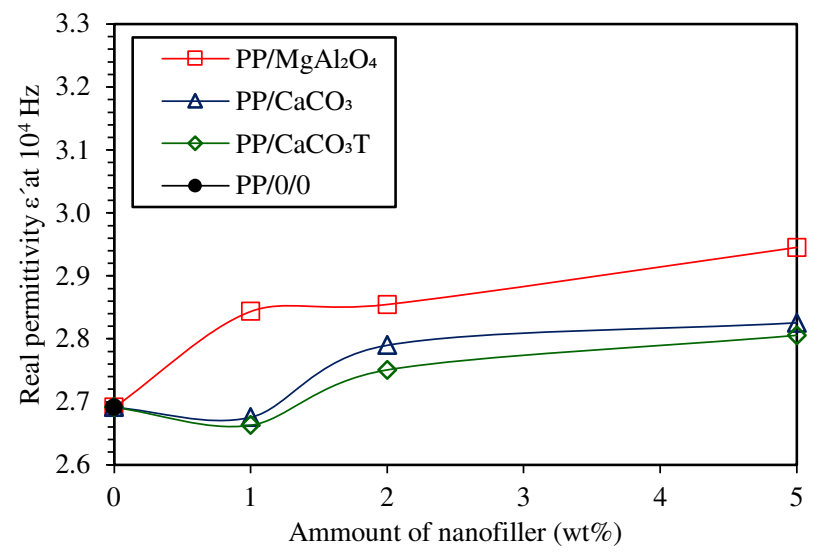

(b)

Figure 7. (a) Real permittivity, (b) permittivity at $10 \mathrm{kHz}$ of unfilled $\mathrm{PP}$ and nanocomposites containing $\mathrm{MgAl}_{2} \mathrm{O}_{4}, \mathrm{CaCO}_{3}$, and $\mathrm{CaCO}_{3} \mathrm{~T}$.

increasing $\mathrm{MgAl}_{2} \mathrm{O}_{4}$ loading level and the beneficial effects of any interphase regions are consequently diminished. Indeed, results from dielectric spectroscopy measurements suggest that the reduced AC breakdown strength is in line with the increased $\varepsilon$ 'values of nanocomposites that occur with increasing loading 


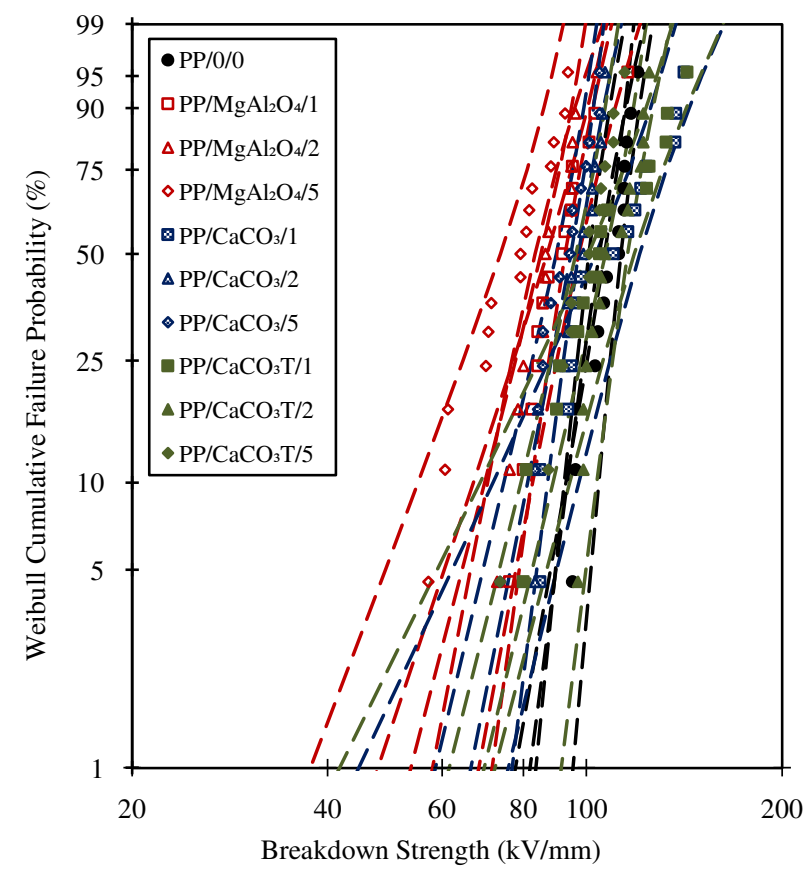

(a)

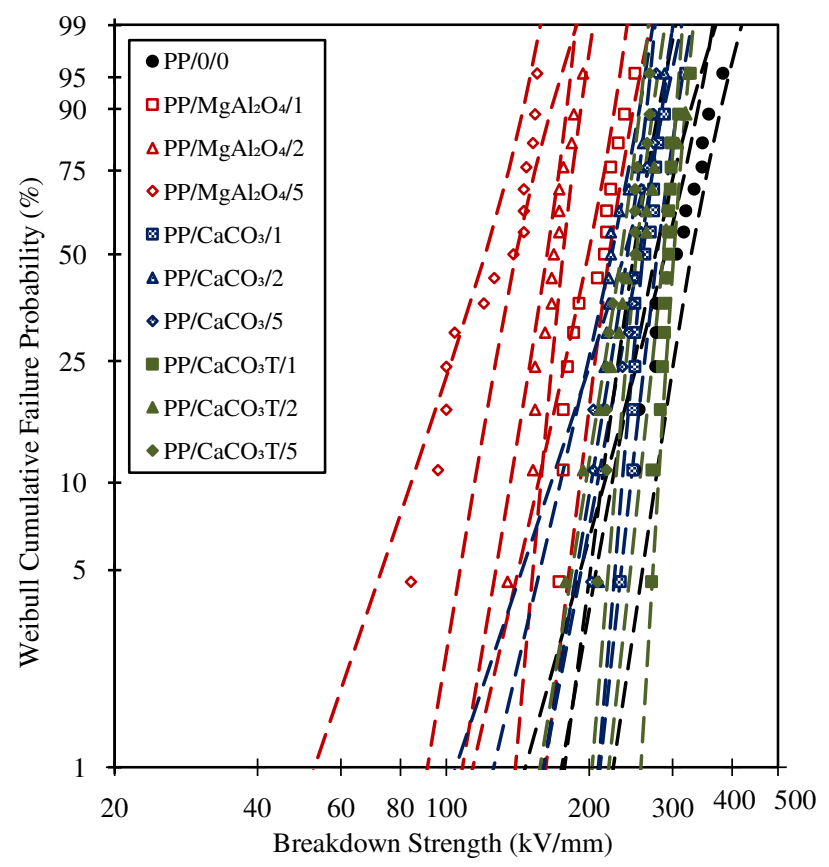

(b)

Figure 8. Weibull plots for comparing the (a) AC and (b) DC breakdown strength of $\mathrm{PP} / 0 / 0$ and nanocomposites containing $\mathrm{MgAl}_{2} \mathrm{O}_{3}, \mathrm{CaCO}_{3}$, and $\mathrm{CaCO}_{3} \mathrm{~T}$.

Table 3. AC and DC breakdown parameters.

\begin{tabular}{|c|c|c|c|c|}
\hline \multirow{2}{*}{ Sample } & \multicolumn{2}{|l|}{$\mathbf{A C}$} & \multicolumn{2}{|l|}{ DC } \\
\hline & $\alpha_{A C}\left(\mathbf{k V m m}^{-1}\right)$ & $\boldsymbol{\beta}_{A C}$ & $\alpha_{D C}\left(\mathbf{k V m m}^{-1}\right)$ & $\beta_{D C}$ \\
\hline $\mathrm{PP} / 0 / 0$ & $112 \pm 3$ & $17 \pm 8$ & $323 \pm 18$ & $8 \pm 3$ \\
\hline $\mathrm{PP} / \mathrm{MgAl}_{2} \mathrm{O}_{4} / 1$ & $96 \pm 5$ & $9 \pm 3$ & $218 \pm 10$ & $10 \pm 4$ \\
\hline $\mathrm{PP} / \mathrm{MgAl}_{2} \mathrm{O}_{4} / 2$ & $91 \pm 4$ & $12 \pm 4$ & $174 \pm 6$ & $13 \pm 5$ \\
\hline $\mathrm{PP} / \mathrm{MgAl}_{2} \mathrm{O}_{4} / 5$ & $82 \pm 5$ & $8 \pm 3$ & $137 \pm 10$ & $7 \pm 3$ \\
\hline $\mathrm{PP} / \mathrm{CaCO}_{3} / 1$ & $118 \pm 9$ & $6 \pm 3$ & $275 \pm 11$ & $11 \pm 4$ \\
\hline $\mathrm{PP} / \mathrm{CaCO}_{3} / 2$ & $100 \pm 3$ & $16 \pm 6$ & $245 \pm 12$ & $9 \pm 3$ \\
\hline $\mathrm{PP} / \mathrm{CaCO}_{3} / 5$ & $96 \pm 4$ & $13 \pm 5$ & $257 \pm 9$ & $14 \pm 5$ \\
\hline $\mathrm{PP} / \mathrm{CaCO}_{3} \mathrm{~T} / 1$ & $116 \pm 9$ & $6 \pm 3$ & $300 \pm 7$ & $20 \pm 7$ \\
\hline $\mathrm{PP} / \mathrm{CaCO}_{3} \mathrm{~T} / 2$ & $115 \pm 4$ & $13 \pm 5$ & $271 \pm 19$ & $7 \pm 2$ \\
\hline $\mathrm{PP} / \mathrm{CaCO}_{3} \mathrm{~T} / 5$ & $103 \pm 4$ & $12 \pm 5$ & $249 \pm 8$ & $14 \pm 6$ \\
\hline
\end{tabular}

(hence agglomeration - see Figure 6) of $\mathrm{MgAl}_{2} \mathrm{O}_{4}$. For nanocomposites containing $\mathrm{CaCO}_{3}$, the above assertion implies that the aforementioned permittivity effects are less pronounced, such that nanocomposites containing $\mathrm{CaCO}_{3}$ exhibit higher $\mathrm{AC}$ breakdown strengths than systems containing equivalent amounts of $\mathrm{MgAl}_{2} \mathrm{O}_{4}$. However, the permittivity of bulk $\mathrm{CaCO}_{3}\left(\varepsilon^{\prime}=8.8\right.$ [38]) is not markedly different from that of bulk $\mathrm{MgAl}_{2} \mathrm{O}_{4}\left(\varepsilon^{\prime}=8.4\right.$ [37] $)$, while the measured permittivity of nanocomposites based on the former nanofiller is consistently lower than the measured permittivity of nanocomposites based on the latter (see Figure 7). While it could be inferred from this that the nanofiller dispersion of $\mathrm{CaCO}_{3}$ is generally better than in the case of $\mathrm{MgAl}_{2} \mathrm{O}_{4}$, the SEM micrographs in Figure 6 provide no compelling evidence for this. As such, we therefore suggest the following: the reduced permittivity seen in the $\mathrm{CaCO}_{3}$-based systems is a consequence of local, interfacial effects that occur in these materials; these differ from those that occur in equivalent $\mathrm{MgAl}_{2} \mathrm{O}_{4}$-containing nanocomposites; these differences result in the relative suppression of $\varepsilon$ ' and relative elevation of breakdown strength seen in the $\mathrm{CaCO}_{3}$-based nanocomposites, compared to those containing $\mathrm{MgAl}_{2} \mathrm{O}_{4}$.

To examine further the association between the measured real part of the permittivity and changes in AC breakdown strength, consider now the effect of $\mathrm{CaCO}_{3}$ surface modification. From Figure 7, the influence of nanofiller surface modification on $\varepsilon$ ' appears negligible, with the exception of the systems containing $2 \mathrm{wt} \%$ of each nanofiller, where the $\varepsilon$ ' of $\mathrm{PP} / \mathrm{CaCO}_{3} \mathrm{~T} / 2$ is noticeably lower than that of $\mathrm{PP} / \mathrm{CaCO}_{3} / 2$. Similarly, the measured $\mathrm{AC}$ breakdown strength of equivalent $\mathrm{PP} / \mathrm{CaCO}_{3} \mathrm{~T}$ and $\mathrm{PP} / \mathrm{CaCO}_{3}$ systems is the same, when the confidence bounds are taken into account, except for $\mathrm{PP} / \mathrm{CaCO}_{3} / 2$ $\left(100 \pm 3 \mathrm{kV} \mathrm{mm}^{-1}\right)$ and $\mathrm{PP} / \mathrm{CaCO}_{3} \mathrm{~T} / 2\left(115 \pm 4 \mathrm{kV} \mathrm{mm}^{-1}\right)$. The system with the lower measured $\varepsilon$ ' value, again, exhibits a higher breakdown strength. However, the fact that surface modification does not universally reduce $\varepsilon$ ' or increase AC breakdown strength suggests that modifying the surface chemistry of nanofillers per se has little effect on nanocomposites as far as AC breakdown is concerned, as demonstrated elsewhere [26].

Meanwhile, Figure $8 \mathrm{~b}$ compares Weibull plots of the DC breakdown strength of unfilled $\mathrm{PP}$ and nanocomposites containing $\mathrm{MgAl}_{2} \mathrm{O}_{4}, \mathrm{CaCO}_{3}$, and $\mathrm{CaCO}_{3} \mathrm{~T}$; derived Weibull parameters are, again, listed in Table 3. For the reference, unfilled PP, the measured DC breakdown strength is $323 \pm 18 \mathrm{kV} \mathrm{mm}^{-1}$. It should be noted that experimental breakdown results depend on many parameters, including the sample thickness, the electrode geometry, and the surrounding medium [39]. The breakdown strength of the unfilled PP seen here is by no means universal, but is sensible for comparative assessment purposes; similar range of breakdown strength of unfilled PP has been reported elsewhere [40]. By adding $\mathrm{MgAl}_{2} \mathrm{O}_{4}$ to $\mathrm{PP}$, the DC breakdown strength reduced significantly to $218 \pm 10 \mathrm{kV} \mathrm{mm}^{-1}, 174 \pm 6 \mathrm{kV} \mathrm{mm} \mathrm{mm}^{-1}$, and $137 \pm 10 \mathrm{kV} \mathrm{mm} \mathrm{mm}^{-1}$ for 1,2 , and $5 \mathrm{wt} \%$ loading levels, respectively. While a contributory factor to this reduction may be increasing levels of agglomeration, we suggest that the introduction of polar surfaces and the consequent presence of adsorbed water is also important. Indeed, both the dielectric and 
TGA data point to the presence of adsorbed water in this system. Guo et al. [41] reported that increased nanofiller agglomeration at high filler loading levels resulted in increased electrical conduction; electrical conduction is further enhanced through the presence of water within the nanocomposites, which subsequently leads to a reduction in the DC breakdown strength [26].

The addition of $\mathrm{CaCO}_{3}$ to $\mathrm{PP}$ also results in a reduction in $\mathrm{DC}$ breakdown strength and, as above, the value of this parameter decreases with increasing nanofiller loading. Although the DC breakdown strength of $\mathrm{PP} / \mathrm{CaCO}_{3} / 5$ appears slightly higher than $\mathrm{PP} / \mathrm{CaCO}_{3} / 2$, this falls within measurement uncertainties. Our past experience from DC breakdown testing [26, 29] suggests that reduced DC breakdown strength with increasing nanofiller loading is a more likely phenomenon, as is the case here. Comparing the behavior of equivalent loaded $\mathrm{CaCO}_{3}$ systems with $\mathrm{MgAl}_{2} \mathrm{O}_{4}$ systems shows that the $\mathrm{DC}$ breakdown reduction in $\mathrm{CaCO}_{3}$ systems is less pronounced than for systems containing $\mathrm{MgAl}_{2} \mathrm{O}_{4}$. We suggest that this is a consequence of the presence of fewer adsorbed water molecules around $\mathrm{CaCO}_{3}$, such that the reduction in DC breakdown strength is consequently diminished. This is consistent with the TGA data presented above, where a negligible mass change was seen around $100{ }^{\circ} \mathrm{C}$ in this system, and the dielectric data, where no increase in $\varepsilon$ ' with decreasing frequency is evident for any of the systems containing $\mathrm{CaCO}_{3}$.

Surface modification leads to a modest improvement in the DC breakdown strength of nanocomposites containing $1 \mathrm{wt} \%$ and $2 \mathrm{wt} \%$ of $\mathrm{CaCO}_{3} \mathrm{~T}$, compared to systems containing an equivalent amount of $\mathrm{CaCO}_{3}$. There is no statistically significant difference in the DC breakdown strength of $\mathrm{PP} / \mathrm{CaCO}_{3} \mathrm{~T} / 5$ and $\mathrm{PP} / \mathrm{CaCO}_{3} / 5$. Furthermore, the DC breakdown strength of $\mathrm{PP} / \mathrm{CaCO}_{3} \mathrm{~T} / 1$ is $300 \pm 7 \mathrm{kV} \mathrm{mm}^{-1}$; this value is comparable to the unfilled PP when measurement uncertainties are taken into account. It is therefore proposed that the improved DC breakdown performance of $\mathrm{CaCO}_{3} \mathrm{~T}$ compared to $\mathrm{CaCO}_{3}$ at low nanofiller loading may be a consequence of electrical conduction effects becoming less dominant over the favorable nanofiller/polymer interactions at large separations between nanoparticles. According to Zha et al. [35], agglomeration of nanoparticles (as seen in the $\mathrm{CaCO}_{3}$ systems here) jeopardizes nanofiller/polymer interactions and results in increased conductivity. At low nanofiller loading and enhanced nanofiller/polymer interactions (as anticipated for the $\mathrm{CaCO}_{3} \mathrm{~T}$ systems here), however, charge carriers will be captured by the potential well that originates from the nanofiller/polymer interphase, which subsequently reduces the charge transport rate and results in decreased conductivity. Meanwhile, the addition of surface modified nanoparticles to polymers also introduce deep traps that can effectively capture charge carriers and reduce charge carrier migration. Indeed, it has been suggested that enhanced interactions between nanoparticles and adjacent polymer molecules (as anticipated for the $\mathrm{CaCO}_{3} \mathrm{~T}$ systems here) inhibit charge transport mechanisms within the interphase of nanocomposites, which is favorable for DC breakdown improvements [35]. Of note, the importance of nanofiller dispersion and nanofiller/polymer interactions in determining the dielectric properties of nanocomposites has also been emphasized by Pang et al. [42].

\section{CONCLUSIONS}

The current work reports on the dielectric effects of adding multi-element oxide nanofillers, i.e., $\mathrm{MgAl}_{2} \mathrm{O}_{4}, \mathrm{CaCO}_{3}$, and $\mathrm{CaCO}_{3} \mathrm{~T}$, to PP. The observed reduction in the $\mathrm{AC}$ breakdown strength of the investigated $\mathrm{MgAl}_{2} \mathrm{O}_{4}, \mathrm{CaCO}_{3}$, and $\mathrm{CaCO}_{3} \mathrm{~T}$ based nanocomposites with increasing nanofiller loading levels is associated with an increase in the local electric field that arises as a consequence of permittivity mismatches between the two components, which is exacerbated by nanofiller agglomeration. While better interfacial effects within the nanocomposites can be achieved through the use of $\mathrm{CaCO}_{3}$ compared to $\mathrm{MgAl}_{2} \mathrm{O}_{4}$, such that electric field intensification factors become less dominant, data from AC breakdown suggest that further enhanced nanofiller/polymer interactions through nanofiller surface modification $\left(\mathrm{CaCO}_{3} \mathrm{~T}\right)$ are less apparent under AC fields. Nevertheless, data from DC breakdown testing suggest that dielectric changes associated with nanofiller/polymer interactions are more noticeable under DC fields. Although we anticipate that electrical conduction mechanisms within the nanocomposites are critical under DC fields, and this can be mitigated in the absence of water conduction mechanisms, a potentially favorable DC breakdown strength at relatively low $\mathrm{CaCO}_{3} \mathrm{~T}$ loading can be ascribed to further improved interactions between $\mathrm{CaCO}_{3} \mathrm{~T}$ and PP after nanofiller surface modification, such that electrical conduction effects become less dominant over favorable nanofiller/polymer interactions. Significantly, the use of different multi-element oxide nanofillers in the current polypropylene system demonstrates the importance of engineering the local interactions between nanoparticles and polymer to achieve desirable dielectric properties. It is noteworthy that the current work focuses on the structuredielectric property relationship of the investigated nanocomposites with no consideration of their mechanical properties. For the materials to be feasibly used as cable insulation possessing reasonable dielectric behaviors and acceptable flexural modulus, changes in mechanical properties need to be considered along with changes in dielectric behaviors of the materials. A study of such issues is ongoing to pave the way for the development of future HVAC and HVDC systems based on nanostructured polypropylene technology.

\section{ACKNOWLEDGMENTS}

The authors thank Malaysia Ministry of Education, Universiti Teknologi Malaysia, and Nippon Sheet Glass Foundation for Materials Science and Engineering for financial sponsorship and the respective Fundamental Research Grant Scheme (FRGS/1/2019/TK04/UTM/02/1 (5F158)), RUG (02M54), and NSG (4B373) research grants. UTM Zamalah scholarship is also acknowledged.

\section{REFERENCES}

[1] T. Tanaka, "Dielectric Nanocomposites with Insulating Properties," IEEE Trans. Dielectr. Electr. Insul., vol. 12, no. 5, pp. 914-928, Oct. 2005.

[2] T. Andritsch, A. Vaughan, and G. C. Stevens, "Novel Insulation Materials for High Voltage Cable Systems," IEEE Electr. Insul. Mag, vol. 33, no. 4, pp. 27-33, Aug. 2017.

[3] X. Huang, Y. Fan, J. Zhang, and P. Jiang, "Polypropylene based thermoplastic polymers for potential recyclable HVDC cable insulation 
applications," IEEE Trans. Dielectr. Electr. Insul., vol. 24, no. 3, pp. 1446-1456, Jun 2017.

[4] I. L. Hosier, A. S. Vaughan, A. Pye, and G. C. Stevens, "High performance polymer blend systems for HVDC applications," IEEE Trans. Dielectr. Electr. Insul., vol. 26, no. 4, pp. 1197-1203, Aug. 2019.

[5] Y. Zhou, J. Hu, B. Dang, and J. He, "Effect of different nanoparticles on tuning electrical properties of polypropylene nanocomposites," IEEE Trans. Dielectr. Electr. Insul., vol. 24, no. 3, pp. 1380-1389, Jun. 2017.

[6] H. Mao, B. He, W. Guo, L. Hua, and Q. Yang, "Effects of Nano-CaCO3 content on the crystallization, mechanical properties, and cell structure of PP nanocomposites in microcellular injection molding," Polymers (Basel)., vol. 10, no. 10, Oct. 2018.

[7] I. L. Hosier, L. Cozzarini, A. S. Vaughan, and S. G. Swingler, "Propylene based systems for high voltage cable insulation applications," in Journal of Physics: Conference Series, 2009, vol. 183, pp. 012015.

[8] C. D. Green et al., "Thermoplastic Cable Insulation Comprising a Blend of Isotactic Polypropylene and a Propylene-ethylene Copolymer," IEEE Trans. Dielectr. Electr. Insul., vol. 22, no. 2, Apr. 2015.

[9] C. Q. Li, J. W. Zha, H. Q. Long, S. J. Wang, D. L. Zhang, and Z. M. Dang, "Mechanical and dielectric properties of graphene incorporated polypropylene nanocomposites using polypropylene-graft-maleic anhydride as a compatibilizer," Compos. Sci. Technol., vol. 153, pp. 111-118, Dec. 2017.

[10] S. Hu, Y. Zhou, C. Yuan, W. Wang, J. Hu, Q. Li, and J. He, "Surfacemodification effect of $\mathrm{MgO}$ nanoparticles on the electrical properties of polypropylene nanocomposites, "High Voltage, vol. 5, no. 3, pp. 249255, Jun 2020.

[11] A. V. Shaw, P. Ketsamee, T. Andritsch, and A. S. Vaughan, "Effect of organoclay loading on the dielectric properties and charge dynamics of a PP-rubber nanocomposite," High Voltage, vol. 5, no. 6, pp. 662-668, Dec. 2020.

[12] J. W. Zha, Q.-Q. Qin, and Z.-M. Dang, "Effect of multi-dimensional zinc oxide on electrical properties of polypropylene nanocomposites for HVDC cables," IEEE Trans. Dielectr. Electr. Insul., vol. 26, no. 3, pp. 868-875, May 2019.

[13] I. Rytöluoto, K. Lahti, M. Karttunen, M. Koponen, S. Virtanen, and M. Pettersson, "Large-area dielectric breakdown performance of polymer films - Part II: Interdependence of filler content, processing and breakdown performance in polypropylene-silica nanocomposites," IEEE Trans. Dielectr. Electr. Insul., vol. 22, no. 4, pp. 2196-2206, Aug. 2015.

[14] S. Dash, R. K. Sahoo, A. Das, S. Bajpai, D. Debasish, and S. K. Singh, "Synthesis of $\mathrm{MgAl}_{2} \mathrm{O}_{4}$ spinel by thermal plasma and its synergetic structural study," J. Alloys Compd., vol. 726, pp. 1186-1194, Dec. 2017.

[15] S. Virtanen et al., "Structure and dielectric breakdown strength of nano calcium carbonate/polypropylene composites," J. Appl. Polym. Sci., vol. 131, no. 1, pp. 1/39504-8/39504, Jan. 2014.

[16] F. W. Clinard, G. F. H. Los, and L. W. Hobbs, "Neutron irradiation damage in $\mathrm{MgO}, \mathrm{Al}_{2} \mathrm{O}_{3}$ and $\mathrm{MgAl}_{2} \mathrm{O}_{4}$ ceramics," J. Nucl. Mater., vol. 108, pp. 655-670, Jul.-Aug. 1982.

[17] J. Qiao and Y. Wen, "Mechanical and dielectric properties of porous magnesium aluminate $\left(\mathrm{MgAl}_{2} \mathrm{O}_{4}\right)$ spinel ceramics fabricated by direct foaming-gelcasting," Ceram. Int., vol. 46, no. 2, pp. 1442-1447, Feb. 2020.

[18] A. Rupaal, J. Garnier, and J. Bates. "Dielectric breakdown of porous $\mathrm{MgAl}_{2} \mathrm{O}_{4}$," J. Am. Ceram. Soc., vol. 64, no. 7, pp. 100-101, Jul. 1981.

[19] F. Pashmforoush, S. Ajori, and H. R. Azimi, "Interfacial characteristics and thermo-mechanical properties of calcium carbonate/polystyrene nanocomposite," Mater. Chem. Phys., vol. 247, pp. 122871, Jun 2020.

[20] E. M. Do Nascimento, D. Eiras, and L. A. Pessan, "Effect of thermal treatment on impact resistance and mechanical properties of polypropylene/calcium carbonate nanocomposites," Compos. Part B Eng., vol. 91, pp. 228-234, Apr. 2016.

[21] M. Avella, S. Cosco, M. L. Di Lorenzo, E. Di Pace, M. E. Errico, and G. Gentile, "Nucleation activity of nanosized $\mathrm{CaCO}_{3}$ on crystallization of isotactic polypropylene, in dependence on crystal modification, particle shape, and coating," Eur. Polym. J., vol. 42, no. 7, pp. 1548-1557, Jul. 2006.

[22] F. Morel, V. Bounor-Legaré, E. Espuche, O. Persyn, and M. Lacroix, "Surface modification of calcium carbonate nanofillers by fluoro- and alkyl-alkoxysilane: Consequences on the morphology, thermal stability and gas barrier properties of polyvinylidene fluoride nanocomposites," Eur. Polym. J., vol. 48, no. 5, pp. 919-929, May 2012.

[23] W. Gao, X. Ma, Y. Liu, Z. Wang, and Y. Zhu, "Effect of calcium carbonate on PET physical properties and thermal stability," Powder
Technol., vol. 244, pp. 45-51, Aug. 2013.

[24] A. Samad, K. Y. Lau, I. A. Khan, A. H. Khoja, M. M. Jaffar, and M. Tahir, "Structure and breakdown property relationship of polyethylene nanocomposites containing laboratory-synthesized alumina, magnesia and magnesium aluminate nanofillers," J. Phys. Chem. Solids, vol. 120, pp. 140-146, Sep. 2018.

[25] X. Huang et al., "Role of interface in highly filled epoxy/BaTiO3 nanocomposites. Part II-effect of nanoparticle surface chemistry on processing, thermal expansion, energy storage and breakdown strength of the nanocomposites," IEEE Trans. Dielectr. Electr. Insul., vol. 21, no. 2, pp. 480-487, Apr. 2014.

[26] N. H. Rahim, K. Y. Lau, N. A. Muhamad, N. Mohamad, W. A. W. A. Rahman, and A. S. Vaughan, "Effects of filler calcination on structure and dielectric properties of polyethylene/silica nanocomposites," IEEE Trans. Dielectr. Electr. Insul., vol. 26, no. 1, pp. 284-291, Jan. 2019.

[27] H. Essabir, M. O. Bensalah, D. Rodrigue, R. Bouhfid, and A. el kacem Qaiss, "A comparison between bio- and mineral calcium carbonate on the properties of polypropylene composites," Constr. Build. Mater., vol. 134, no. 2017, pp. 549-555, Mar. 2017.

[28] M. Rahmani, F. A. Ghasemi, and G. Payganeh, "Effect of surface modification of calcium carbonate nanoparticles on their dispersion in the polypropylene matrix using stearic acid," Mech. Ind., vol. 15, no. 1, pp. 63-67, Apr. 2014.

[29] N. H. Rahim, K. Y. Lau, N. A. Muhamad, N. Mohamad, C. W. Tan, and A. S. Vaughan, "Structure and dielectric properties of polyethylene nanocomposites containing calcined zirconia," IEEE Trans. Dielectr. Electr. Insul., vol. 26, no. 5, pp. 1541-1548, Oct. 2019.

[30] L. Zhang, Y. Zhang, Y. Zhou, C. Teng, Z. Peng, and S. Spinella, "Crystalline modification and its effects on dielectric breakdown strength and space charge behavior in isotactic polypropylene," Polymers (Basel)., vol. 10, no. 4, pp.1-14, Apr. 2018.

[31] J. Liu, Y. Wang, K. Xiao, and Z. Zhang, "Research on the thermal aging behaviors of $\mathrm{LDPE} / \mathrm{TiO}_{2}$ nanocomposites," J. Nanomater., vol. 2017, pp. $0-11$, Jun 2017.

[32] W. Wan, D. Yu, Y. Xie, X. Guo, Z. Mao, and L. Huang, "Effects of Nanoparticle Surface Treatment on the Crystalline Morphology and Dielectric Property of Polypropylene/ Calcium Carbonate Nanocomposites," in IEEE Int. Conf. Nano/Micro Engineered and Molecular Systems, 2006, pp. 387-390.

[33] I. L. Hosier, M. Praeger, A. S. Vaughan, and S. G. Swingler, "The effects of water on the dielectric properties of silicon based nanocomposites," IEEE Trans. Nanotechnol., vol. 16, no. 2, pp. 169-179, Mar. 2017.

[34] I. L. Hosier, M. Praeger, A. S. Vaughan, and S. G. Swingler, "The effects of water on the dielectric properties of aluminum-based nanocomposites," IEEE Trans. Nanotechnol., vol. 16, no. 4, pp. 667676, Jul. 2017.

[35] J. W. Zha, J. F. Wang, S. J. Wang, Q. Qin, and Z. M. Dang, "Effect of modified $\mathrm{ZnO}$ on electrical properties of PP/SEBS nanocomposites for HVDC cables," IEEE Trans. Dielectr. Electr. Insul., vol. 25, no. 6, pp. 2358-2365, Dec. 2018.

[36] S. N. Kolesov, "The influence of morphology on the electric strength of polymer insulation," IEEE Trans. Electr. Insul., vol. 15, no. 5, pp. 382388, Oct. 1980.

[37] R. D. Shannon E and G. R. Rossman, "Dielectric constant of $\mathrm{MgAl}_{2} \mathrm{O}_{4}$ spinel and the oxide additivity rule," J. Phys. Chem. Solids, vol. 52, no. 9, pp. 1055-1059, Mar. 1991.

[38] A. H. Scott and A. T. McPherson, "Dielectric constant, power factor, and conductivity of the system rubber-calcium carbonate," J. Research National Bureau of Standards, vol. 28, pp. 279-296, Mar. 1942.

[39] Standard Test Method for Dielectric Breakdown Voltage and Dielectric Strength of Solid Electrical Insulating Materials at Commercial Power Frequencies, ASTM Standard D149 - 09 (Reapproved 2013), 2013.

[40] B. X. Du, H. Xu, J. Li, and Z. Li, "Space Charge Behaviors of PP/POE/ZnO Nanocomposites for HVDC Cables," IEEE Trans. Dielectr. Electr. Insul., vol. 23, Oct. 2016

[41] W. Guo, B. Han, and Z. Li, "DC voltage current characteristic of Silicon Carbide/ low-density polyethylene composites," in 2010 International Forum on Strategic Technology, IFOST 2010, 2010, pp. 365-368.

[42] X. Pang et al., "Block copolymer/ferroelectric nanoparticle nanocomposites," Nanoscale, vol. 5, no. 18, pp. 8695-8702, Oct. 2013. 